\title{
Photocleavage Properties and DNA-Binding Studies of Oxovanadium Complexes Incorporating 2-(2-Hydroxybenzylideneamino) Isoindoline-1,3-Dione and Fluoro-Phenanthroline Derivatives
}

\author{
Peng Ying1, Pengfei Zeng1, Jiazheng Lu ${ }^{1 *}$, Ning Yang², Hongyuan Chen ${ }^{3 *}$ \\ ${ }^{1}$ School of Pharmacy, Guangdong Pharmaceutical University, Guangzhou, China \\ ${ }^{2}$ Department of Clinical Pathology, the First Affiliated Hospital, Guangdong Pharmaceutical University, \\ Guangzhou, China \\ ${ }^{3}$ Department of Pathogen Biology and Immunology, School of Basic Course, Guangdong Pharmaceutical \\ University, Guangzhou, China \\ Email: ${ }^{*}$ lujia6812@163.com, ${ }^{*}$ hychen1208@126.com
}

Received 22 July 2014; revised 20 August 2014; accepted 15 September 2014

Copyright (C) 2014 by authors and Scientific Research Publishing Inc.

This work is licensed under the Creative Commons Attribution International License (CC BY).

http://creativecommons.org/licenses/by/4.0/

c) (i) Open Access

\section{Abstract}

Three mononuclear oxovanadium complexes [VO(Hbid) $\left.\left(\mathrm{CF}_{3} \mathrm{PIP}\right)\right]$ (1) (Hbid=(E)-2-(2-hydroxybenzylideneamino)isoindoline-1,3-dione, $\mathrm{CF}_{3} \mathrm{PIP}=2$-(2-trifluoromethyl phenyl)imidazole $[4,5-\mathrm{f}][1,10]$ phenanthroline), [VO(Hbid)(m-CF $\left.\left.{ }_{3} \mathrm{PIP}\right)\right]$; (2) ( $\mathrm{m}-\mathrm{CF}_{3} \mathrm{PIP}=2$-(3-trifluoromethyl phenyl)imidazole [4, 5-f][1,10]phenanthroline) and [VO(Hbid)(p-CF 3 PIP)]; (3) (p-CF 3 PIP=2-(4-trifluoromethyl phenyl) imidazole[4,5-f][1,10]phenanthroline) have been synthesized and characterized by elemental analysis, IR, molar conductance, ES-MS and ${ }^{1} \mathrm{H}$ NMR. The DNA-binding properties of these complexes were studied by using UV-Vis absorption titration, fluorescence spectra, viscosity measurements and thermal denaturation studies. The results show that 1, 2 and 3 interact with calf thymus DNA (CT-DNA) by intercalation modes and the magnitude of their intrinsic binding constants $\left(K_{b}\right.$ values) follows the order: $2<1<3$. Furthermore, their photocleavage properties with pBR322 plasmid DNA were investigated by agarose gel electrophoresis experiments. The DNA cleavage capacity of complex 3 is also stronger than that of 1 and 2 .

${ }^{*}$ Corresponding authors.

How to cite this paper: Ying, P., et al. (2014) Photocleavage Properties and DNA-Binding Studies of Oxovanadium Complexes Incorporating 2-(2-Hydroxybenzylideneamino) Isoindoline-1,3-Dione and Fluoro-Phenanthroline Derivatives. Open Journal of Inorganic Chemistry, 4, 51-63. http://dx.doi.org/10.4236/ojic.2014.44007 


\section{Keywords}

\section{Oxovanadium Complexes, Synthesis, DNA-Binding, Photocleavage}

\section{Introduction}

The development of transition metal complexes which are actually to be utilized in a wide range of biochemistry and medicine as well as therapeutic medication against tumor cells has achieved fantastic step forward in past decades [1]-[3]. Oxovanadium complexes as one group of transition metal compounds have aroused great interest among biochemists and pharmacologists owing to diverse biologic and pharmacological activities such as antiproliferative [4], antibacterial [5], biocatalytic oxidation [6] [7], insulin-enhancing effects [8], apoptosis-inducing activity [9] [10], potential capabilities as DNA structural probes and DNA dependent electron transfer likewise [11] [12]. In recent years, mixed-ligand oxovanadium complexes have demonstrated both in vitro antibacterial and antifungal properties [13] as well as intense interactions with DNA [14] [15].

Complexes with Schiff base Hbid, where Hbid=(E)-2-(2-hydroxybenzylideneamino) isoindoline-1,3-dione, displayed chemical nuclease activity by partial intercalation thus ability to inhibit the growth of both Gram-pos. and Gram-neg. bacteria [16] [17]. Imidazole[4, 5-f][1, 10] phenanthroline derivatives available to inhibit c-myc gene expression in A549 cells via NF-kB pathway exhibit certain activities towards inhibiting tumor cells to some extend [18]-[20]. Although certain attention has been paid to the research on oxovanadium complexes as potential DNA intercalator, photocleavage and anticancer agents [21]-[24], the oxovanadium compounds with imidazole[4, 5-f][1, 10] fluoro-phenanthroline derivatives has rarely been reported yet [22] [25].

In the present article, three mononuclear oxovanadium complexes [VO(Hbid)(CF $\left.\left.\mathrm{CF}_{3} \mathrm{PIP}\right)\right](\mathbf{1})$, [VO(Hbid)(mCF3PIP)] (2), [VO(Hbid)(p-CF $\left.\left.{ }_{3} \mathrm{PIP}\right)\right]$ (3), (Hbid=(E)-2-(2-hydroxybenzylideneamino)isoindoline-1,3-dione, $\mathrm{CF}_{3} \mathrm{PIP}=-\left(2\right.$-trifluoromethyl phenyl)imidazole $[4,5-\mathrm{f}][1,10]$ phenanthroline, $\mathrm{m}-\mathrm{CF}_{3} \mathrm{PIP}=2$-(3-trifluoromethyl phenyl)imidazole[4,5-f][1,10]phenanthroline, $\quad$ p- $\mathrm{CF}_{3} \mathrm{PIP}=2$-(4-trifluoromethyl phenyl)imidazole[4,5-f][1,10] phenanthroline) have been synthesized and characterized by elemental analysis, IR, molar conductance, ES-MS and ${ }^{1} \mathrm{H}$ NMR. The DNA-binding properties of these three complexes were well studied by UV-Vis titration, fluorescence spectra, viscosity measurements and thermal denaturation studies. Photocleavage reactions with pBR322 supercolied plasmid DNA were investigated by agarose gel electrophoresis experiments. The compounds employed in this work are shown in Scheme 1.

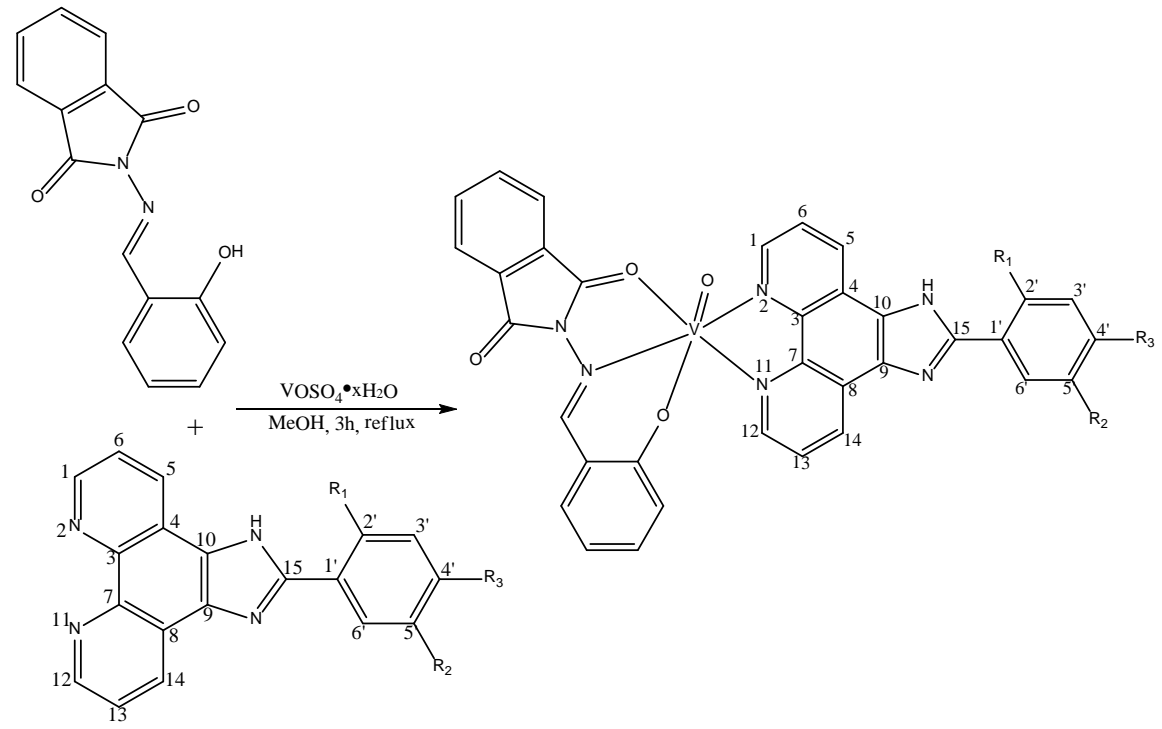

Scheme 1. Structure of $\mathrm{VO}(\mathrm{Hbid})\left(\mathrm{CF}_{3} \mathrm{PIP}\right)(\mathbf{1}), \mathrm{R}_{1}=\mathrm{CF}_{3}, \mathrm{R}_{2}=\mathrm{H}, \mathrm{R}_{3}=\mathrm{H}$; $\mathrm{VO}(\mathrm{Hbid})\left(\mathrm{m}-\mathrm{CF}_{3^{-}}\right.$ PIP) (2), $\mathrm{R}_{1}=\mathrm{H}, \mathrm{R}_{2}=\mathrm{CF}_{3}, \mathrm{R}_{3}=\mathrm{H}$; VO(Hbid) (p-CF $\mathrm{CF}_{3} \mathrm{PP}$ ) (3), $\mathrm{R}_{1}=\mathrm{H}, \mathrm{R}_{2}=\mathrm{H}, \mathrm{R}_{3}=\mathrm{CF}_{3}$. 


\section{Experimental}

\subsection{Materials and Methods}

All chemicals used in the synthesis and physical measurements were analytical reagent grade or biochemical quality and without further purification unless otherwise specified. 1,10-Phenanthroline was obtained from Guangzhou Chemical Reagent Factory. $\mathrm{VOSO}_{4} \cdot \mathrm{xH}_{2} \mathrm{O}$ were purchased from Alfa Aesar, N-Aminophthalimide were purchased from TCI, CT-DNA and pBR322 supercoiled plasmid DNA were obtained from Sigma. Tris buffer 1 (Tris=tris(hydroxyl-methyl)aminomethane) containing $5 \mathrm{~m} \cdot \mathrm{mol} \cdot \mathrm{L}^{-1}$ Tris- $\mathrm{HCl}$ and $50 \mathrm{~m} \cdot \mathrm{mol} \cdot \mathrm{L}^{-1} \mathrm{NaCl}$ $(\mathrm{pH}=7.2)$ was used for absorption titration, fluorescence emission and viscosity measurements. Tris buffer 2 containing $50 \mathrm{~m} \cdot \mathrm{mol} \cdot \mathrm{L}^{-1}$ Tris-HCl and $18 \mathrm{~m} \cdot \mathrm{mol} \cdot \mathrm{L}^{-1} \mathrm{NaCl}(\mathrm{pH}=7.2)$ was used for the gel electrophoresis experiments. A phosphoric acid buffer containing $1.5 \mathrm{~m} \cdot \mathrm{mol} \cdot \mathrm{L}^{-1} \mathrm{Na}_{2} \mathrm{HPO}_{4}, 0.5 \mathrm{~m} \cdot \mathrm{mol} \cdot \mathrm{L}^{-1} \mathrm{NaH}_{2} \mathrm{PO}_{4}$ and $0.25 \mathrm{~m}$. $\mathrm{mol} \cdot \mathrm{L}^{-1} \mathrm{Na}_{2} \mathrm{H}_{2}$ EDTA $\left(\mathrm{H}_{4}\right.$ EDTA=N,N'-ethane-1,2-diylbis[N-(carboxymethyl) glycine]) $(\mathrm{pH}=7.0$ ) was used for thermal denaturation. A solution of CT-DNA in buffer 1 gave a ratio of UV absorbance at 260 and $280 \mathrm{~nm}$ of 1.8 - 1.9:1, indicating that the DNA was sufficiently free of protein [26] [27]. The DNA concentration per nucleotide was determined by absorption spectroscopy using the molar absorption coefficient $\left(6600 \mathrm{M}^{-1} \cdot \mathrm{cm}^{-1}\right)$ at $260 \mathrm{~nm}$ [28]. The complexes were dissolved in DMSO and diluted with buffer solution to the required concentrations prior to use. Hbid, (E)-2-(2-hydroxybenzylideneamino) isoindoline-1,3-dione were synthesized according to a previously reported procedure [16].

\subsection{Physical Measurements}

Microanalysis (C, H, and N) was carried out with a PerkinElmer 240Q elemental analyzer. Electrospray mass spectra (ES-MS) were recorded on an LCQ system (Finnigan MAT, USA) using methanol as mobile phase. ${ }^{1} \mathrm{H}$ NMR spectra were recorded on a Varian-500 spectrometer. All chemical shifts are given relative to tetramethylsilane (TMS). Infrared spectra were recorded on a Bomem FTIR model MB102 instrument using KBr pellets method. UV-Vis spectra were recorded on a Shimadzu UV-3101 PC spectrophotometer at room temperature. Emission spectra were recorded on a Perkin-Elmer Lambda 55 spectrofluorophotometer. Molar conductivities in DMF $\left(1 \mathrm{~m} \cdot \mathrm{mol} \cdot \mathrm{L}^{-1}\right)$ solution at room temperature were measured using a DDS-307 digital direct reading conductivity meter.

\subsection{Synthesis and Characterization}

\subsubsection{Synthesis of Phenanthroline-Based Ligands: $\mathrm{CF}_{3} \mathrm{PIP}, \mathrm{m}-\mathrm{CF}_{3} \mathrm{PIP}$ and $\mathrm{p}-\mathrm{CF}_{3} \mathrm{PIP}$}

$\mathrm{CF}_{3} \mathrm{PIP}$ was synthesized through a modification of a previously reported procedure [29]-[31]. A mixture of 2(Trifluoromethyl)benzaldehyde $(0.69 \mathrm{~mL}, 5 \mathrm{~m} \cdot \mathrm{mol})$ and ammonium acetate $(7.70 \mathrm{~g}, 0.1 \mathrm{~mol})$ was added into a stirring solution of 1,10-Phenanthroline-5,6-dione $(0.99 \mathrm{~g}, 5 \mathrm{~m} \cdot \mathrm{mol})$ in $60 \mathrm{~mL}$ of glacial acetic acid, and the mixture was continuously stirred at $60^{\circ} \mathrm{C}$ for 6 hours. Then the deep red solution was cooled to room temperature and diluted with $100 \mathrm{~mL}$ distilled water. A grayish yellow precipitate was obtained by neutralization with ammonium hydroxide. Then the mixture was filtered and washed with water for three times. The crude solid power was purified by chromatography over 60 - 80 mesh $\mathrm{SiO}_{2}$ using absolute ethanol as eluent. The solvent was removed and the products were collected, and dried in vacuo. $\mathrm{m}-\mathrm{CF}_{3} \mathrm{PIP}$ and $\mathrm{p}-\mathrm{CF}_{3} \mathrm{PIP}$ were prepared by a similar procedure with the compound $\mathrm{CF}_{3} \mathrm{PIP}$, with 3-(Trifluoromethyl)benzaldehyde $(0.69 \mathrm{~mL}, 5 \mathrm{~m} \cdot \mathrm{mol})$ and 4-(Trifluoromethyl)benzaldehyde $(0.69 \mathrm{ml}, 5 \mathrm{~m} \cdot \mathrm{mol})$ in place of 2-(Trifluoromethyl)benzaldehyde $(0.69 \mathrm{~mL}, 5$ $\mathrm{m} \cdot \mathrm{mol})$ respectively, and a pink-yellow precipitate were obtained.

$\mathrm{CF}_{3}$ PIP: Yield: 61\%. Anal. Found: $\mathrm{C}, 65.48 ; \mathrm{H}, 3.14 ; \mathrm{N}, 15.35$; Calcd for $\mathrm{C}_{20} \mathrm{H}_{11} \mathrm{~F}_{3} \mathrm{~N}_{4}$ : C, 65.93; H, 3.04; N, 15.28. ${ }^{1} \mathrm{H}$ NMR (DMSO-d $\left.\mathrm{d}_{6}, 500 \mathrm{MHz}\right) \delta: 9.03$ (s, $2 \mathrm{H}, \mathrm{J}=8.7 \mathrm{~Hz}, \mathrm{ArH}$ ), 9.02 (s, 2H, J = 8.6 Hz, ArH), 8.47 (m, $1 \mathrm{H}, \mathrm{J}=8.3 \mathrm{~Hz}, \mathrm{ArH}), 8.45(\mathrm{~m}, 1 \mathrm{H}, \mathrm{J}=8.2 \mathrm{~Hz}, \mathrm{ArH}), 7.96(\mathrm{~m}, 1 \mathrm{H}, \mathrm{J}=8.1 \mathrm{~Hz}, \mathrm{ArH}), 7.82(\mathrm{br}, 3 \mathrm{H}, \mathrm{J}=7.6 \mathrm{~Hz}$, ArH), 3.32 (s, $1 \mathrm{H},-\mathrm{NH}) .{ }^{13} \mathrm{C}$ NMR (DMSO-d 6 , $\left.500 \mathrm{MHz}\right) \delta$ : $148.9 \mathrm{C}(15), 148.0 \mathrm{C}(1,12), 143.7 \mathrm{C}(5,14), 133.8$ C(3',5'), 129.7 C(1'), $129.5 \mathrm{C}(3), 129.1 \mathrm{C}(7), 126.6 \mathrm{C}\left(2^{\prime}, 6^{\prime}\right), 125.9 \mathrm{C}\left(4^{\prime}\right), 125.8 \mathrm{C}\left(-\mathrm{CF}_{3}\right), 124.8 \mathrm{C}(8), 124.7 \mathrm{C}(4)$, 123.4 C(9), $123.3 \mathrm{C}(10), 122.6 \mathrm{C}(6,13)$. ES-MS: $\left(\mathrm{CH}_{3} \mathrm{OH}\right): \mathrm{m} / \mathrm{z} 365.0\left([\mathrm{M}+\mathrm{H}]^{+}\right), 387.0\left([\mathrm{M}+\mathrm{Na}]^{+}\right) . \mathrm{IR}(\mathrm{KBr}$ disk): $v\left(\mathrm{~cm}^{-1}\right)=3406.8(\mathrm{~s}, \mathrm{~N}-\mathrm{H}), 3078.2(\mathrm{~m}, \mathrm{C}-\mathrm{H}), 1606.7$ (s), $1551.8(\mathrm{~m}), 1483.0$ (s, C=C), 1315.3 (vs, C-F). Conductance $\left(\Omega^{-1} \cdot \mathrm{cm}^{2} \cdot \mathrm{mol}^{-1}\right): 9.2$.

m-CF ${ }_{3}$ PIP: Yield: 58\%. Anal. Found: C, 65.67; H, 3.13; N, 15.42; Calcd for $\mathrm{C}_{20} \mathrm{H}_{11} \mathrm{~F}_{3} \mathrm{~N}_{4}$ : C, 65.93; H, 3.04; $\mathrm{N}$, 15.38. ${ }^{1} \mathrm{H}$ NMR (DMSO-d 6 , $\left.500 \mathrm{MHz}\right) \delta: 8.99$ (m, 2H, J = 8.8 Hz, ArH), 8.83 (d, 2H, J = 8.7 Hz, ArH), 8.56 (m, 
2H, J = 8.2 Hz, ArH), 7.78 (m, 1H, J = $8.0 \mathrm{~Hz}, \mathrm{ArH}), 7.75$ (m, 3H, J = $7.5 \mathrm{~Hz}, \mathrm{ArH}) .3 .38(\mathrm{~s}, 1 \mathrm{H},-\mathrm{NH}) .{ }^{13} \mathrm{C}$ NMR (DMSO-d $\left.\mathrm{d}_{6}, 500 \mathrm{MHz}\right) \delta$ : $148.2 \mathrm{C}(15), 148.0 \mathrm{C}(1,12), 143.6 \mathrm{C}(5,14), 135.3 \mathrm{C}\left(3^{\prime}, 5^{\prime}\right), 132.5 \mathrm{C}\left(1^{\prime}\right), 130.3$ C(3), 129.8 C(7), 128.2 C(2',6'), 127.9 C(4'), 127.0 C(-CF3), $126.8 \mathrm{C}(8), 126.7 \mathrm{C}(4), 126.0 \mathrm{C}(9), 124.8 \mathrm{C}(10)$, 123.8 C(6,13). ES-MS: $\left(\mathrm{CH}_{3} \mathrm{OH}\right): \mathrm{m} / \mathrm{z} 365.0\left([\mathrm{M}+\mathrm{H}]^{+}\right), 387.0\left([\mathrm{M}+\mathrm{Na}]^{+}\right)$. IR $(\mathrm{KBr}$ disk $): v\left(\mathrm{~cm}^{-1}\right)=3241.6(\mathrm{~s}$, N-H), 3065.8, (m, C-H), 1607.2 (m), 1566.7 (s), 1548.5 (m, C=C), 1312.2 (vs, C-F). Conductance ( $\Omega^{-1}$. $\left.\mathrm{cm}^{2} \cdot \mathrm{mol}^{-1}\right): 9.6$.

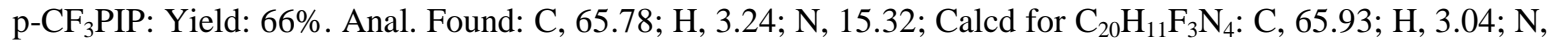
15.38. ${ }^{1} \mathrm{H}$ NMR (DMSO-d 6 , $\left.500 \mathrm{MHz}\right) \delta: 9.07$ (d, 2H, J = 8.6 Hz, ArH), 8.84 (d, 2H, J = 8.4 Hz, ArH), 8.04 (d, $1 \mathrm{H}, \mathrm{J}=8.1 \mathrm{~Hz}, \mathrm{ArH}), 7.97$ (d, 1H, J = 7.8 Hz, ArH), 7.91 (d, 1H, J = 7.9 Hz, ArH), 7.83 (t, 3H, J = 7.7 Hz, ArH). 3.40 (s, $1 \mathrm{H},-\mathrm{NH}) .{ }^{13} \mathrm{C}$ NMR (DMSO-d 6 , $\left.500 \mathrm{MHz}\right) \delta: 149.3 \mathrm{C}(15), 147.7 \mathrm{C}(1,12), 143.6 \mathrm{C}(5,14), 131.6 \mathrm{C}\left(3^{\prime}, 5^{\prime}\right)$, 131.4 C(1'), 130.1 C(3), 129.9 C(7), 129.6 C(2',6'), 128.4 C(4'), $125.5 \mathrm{C}\left(-\mathrm{CF}_{3}\right), 125.2 \mathrm{C}(8), 123.2 \mathrm{C}\left(4^{\prime}\right), 123.1$ $\mathrm{C}(4), 122.4 \mathrm{C}(9), 122.3 \mathrm{C}(10), 121.6 \mathrm{C}(6,13)$. ES-MS: $\left(\mathrm{CH}_{3} \mathrm{OH}\right): \mathrm{m} / \mathrm{z} 365.0\left([\mathrm{M}+\mathrm{H}]^{+}\right), 387.0\left([\mathrm{M}+\mathrm{Na}]^{+}\right) . \mathrm{IR}$ $\left(\mathrm{KBr}\right.$ disk): $v\left(\mathrm{~cm}^{-1}\right)=3371.2(\mathrm{~s}, \mathrm{~N}-\mathrm{H}), 3065.8(\mathrm{w}, \mathrm{C}-\mathrm{H}), 1608.2(\mathrm{~s}), 1565.5$ (m, C=C), 1326.5 (vs, C-F). Conductance $\left(\Omega^{-1} \cdot \mathrm{cm}^{2} \cdot \mathrm{mol}^{-1}\right): 8.6$.

\subsubsection{Synthesis of [VO (Hbid) $\left.\left(\mathrm{CF}_{3} \mathrm{PIP}\right)\right]$ (1)}

[VO (Hbid) $\left(\mathrm{CF}_{3} \mathrm{PIP}\right)$ ] was prepared by the synthetic steps similar to a previously reported method [24] [32] [33]. A mixture of $\mathrm{CF}_{3} \mathrm{PIP}(0.364 \mathrm{~g}, 1 \mathrm{~m} \cdot \mathrm{mol})$ and $\mathrm{Hbid}(0.266 \mathrm{~g}, 1 \mathrm{~m} \cdot \mathrm{mol})$ in absolute $\mathrm{CH}_{3} \mathrm{OH}(60 \mathrm{~mL})$ was heated at $80^{\circ} \mathrm{C}$ under argon for $2 \mathrm{~h}$. After dissolution, an aqueous solution $(5 \mathrm{~mL})$ of $1.0 \mathrm{~m}$ mol $(0.217 \mathrm{~g})$ quantity of $\mathrm{VOSO}_{4} \cdot \mathrm{xH} 2 \mathrm{O}$ was added dropwise to this mixture, and a breen precipitate was formed. The soild power was purified by recrystallization in methanol, and dried in vacuo. Yield: 36\%. Anal. Found: C, 60.28; H, 2.92; N, 12.09; Calcd for $\mathrm{C}_{35} \mathrm{H}_{20} \mathrm{~F}_{3} \mathrm{~N}_{6} \mathrm{O}_{4} \mathrm{~V}$ : C, 60.35; H, 2.89; N, 12.07. ${ }^{1} \mathrm{H}-\mathrm{NMR}$ (DMSO-d $\mathrm{d}_{6}, 500 \mathrm{MHz}$ ) $\delta$ : 9.03 (s, $1 \mathrm{H}$, $\mathrm{CH}=\mathrm{N}$ ), 8.68 (dd, 2H, ArH, J = 8.5 Hz), 8.60 (d, 2H, ArH, J = 8.4 Hz), 8.49 (br, 6H, ArH, J = 8.2 Hz), 8.26 (d, $1 \mathrm{H}, \mathrm{J}=8.4 \mathrm{~Hz}$ ), 8.14 (d, 1H, ArH, J = $7.8 \mathrm{~Hz}$ ), 7.82 (dd, 2H, ArH, J = 7.2 Hz), 7.14 (d, 2H, ArH, J = 6.8 Hz), $6.52(\mathrm{dd}, 2 \mathrm{H}, \mathrm{ArH}, \mathrm{J}=7.8 \mathrm{~Hz}), 5.02(\mathrm{~s}, 1 \mathrm{H},-\mathrm{NH})$. ES-MS $\left(\mathrm{CH}_{3} \mathrm{OH}\right): \mathrm{m} / \mathrm{z}: 695.1\left([\mathrm{M}-\mathrm{H}]{ }^{-}\right), 727.1\left(\left[\mathrm{M}^{-\mathrm{CH}_{3} \mathrm{OH}}-\right.\right.$ $\mathrm{H}^{\top}$ ). IR (KBr disk): $v\left(\mathrm{~cm}^{-1}\right)=3425.1(\mathrm{~N}-\mathrm{H}), 2973.3,3077.0(\mathrm{~m}, \mathrm{C}=\mathrm{C}-\mathrm{H}), 1724.2(\mathrm{vs}, \mathrm{HC}=\mathrm{N}), 1608.0$ (vs, $\mathrm{C}=\mathrm{O}), 1314.1\left(\mathrm{~s},-\mathrm{CF}_{3}\right), 974.1(\mathrm{~s}, \mathrm{~V}=\mathrm{O}), 730.8(\mathrm{~m}, \mathrm{~V}-\mathrm{N})$. Conductance $\left(\Omega^{-1} \cdot \mathrm{cm}^{2} \cdot \mathrm{mol}^{-1}\right): 10.7$.

\subsubsection{Synthesis of [VO (Hbid) (m-CF 3 PIP)] (2)}

This compound was synthesized by a similar procedure as for the complex $\mathbf{1}$, with m-CF $\mathrm{C}_{3} \mathrm{PIP}(0.364 \mathrm{~g}, 1 \mathrm{~m} \cdot \mathrm{mol})$ in place of $\mathrm{CF}_{3} \mathrm{PIP}$. Yield: 43\%. Anal. Found: C, 60.36; $\mathrm{H}, 2.91 ; \mathrm{N}, 12.06$; Calcd for $\mathrm{C}_{35} \mathrm{H}_{20} \mathrm{~F}_{3} \mathrm{~N}_{6} \mathrm{O}_{4} \mathrm{~V}$ : C, 60.35; $\mathrm{H}, 2.89 ; \mathrm{N}, 12.07 .{ }^{1} \mathrm{H}$ NMR (DMSO-d $\left.\mathrm{d}_{6}, 500 \mathrm{MHz}\right) \delta: 8.87(\mathrm{~s}, 1 \mathrm{H}, \mathrm{CH}=\mathrm{N}$ ), 8.59 (dd, 2H, ArH, J = 8.5 Hz), 8.44 (d, 2H, ArH, J = 8.5 Hz), 8.36 (br, 6H, ArH, J = 8.3 Hz), 8.27 (d, 1H, J = 8.2 Hz), 8.08 (d, 1H, ArH, J = 7.7 Hz), 7.72 (dd, 2H, ArH, J = 7.8 Hz), 7.34 (d, 2H, ArH, J = 6.6 Hz), 6.48 (dd, 2H, ArH, J = 7.6 Hz), 5.20 (s, 1H, -NH). ES-MS $\left(\mathrm{CH}_{3} \mathrm{OH}\right): \mathrm{m} / \mathrm{z}: 695.1\left([\mathrm{M}-\mathrm{H}]^{-}\right), 727.1\left(\left[\mathrm{M}+\mathrm{CH}_{3} \mathrm{OH}-\mathrm{H}\right]^{-}\right)$. IR $\left(\mathrm{KBr}\right.$ disk): $v\left(\mathrm{~cm}^{-1}\right)=3428.3(\mathrm{~N}-\mathrm{H})$, $3027.0(\mathrm{~m}, \mathrm{C}=\mathrm{C}-\mathrm{H}), 1721.9(\mathrm{~s}, \mathrm{HC}=\mathrm{N}), 1607.5(\mathrm{vs}, \mathrm{C}=\mathrm{O}), 1312.2\left(\mathrm{~s},-\mathrm{CF}_{3}\right), 968.8(\mathrm{~s}, \mathrm{~V}=\mathrm{O}), 713.7$ (m, V-N). Conductance $\left(\Omega^{-1} \cdot \mathrm{cm}^{2} \cdot \mathrm{mol}^{-1}\right): 9.7$.

\subsubsection{Synthesis of [VO (Hbid) (p-CF 3 PIP)] (3)}

This complex was prepared using a similar procedure described for complex 1. Yield: $36 \%$. Anal. Found: C, 60.28; H, 2.93; N, 12.06; Calcd for $\mathrm{C}_{35} \mathrm{H}_{20} \mathrm{~F}_{3} \mathrm{~N}_{6} \mathrm{O}_{4} \mathrm{~V}$ : C, 60.35; H, 2.89; N, 12.07. ${ }^{1} \mathrm{H}-\mathrm{NMR}$ (DMSO-d $\left.\mathrm{d}_{6}, 500 \mathrm{MHz}\right)$ $\delta$ : $9.12(\mathrm{~s}, 1 \mathrm{H}, \mathrm{CH}=\mathrm{N}), 8.86$ (d, 2H, ArH, J = $8.5 \mathrm{~Hz}$ ), 8.63 (d, 2H, ArH, J = $8.4 \mathrm{~Hz}$ ), 8.44 (br, 6H, ArH, J = 8.2 $\mathrm{Hz}$ ), 8.26 (d, 1H, J = 8.4 Hz), 8.12 (d, 1H, ArH, J = 7.8 Hz), 7.80 (d, 2H, ArH, J = 7.2 Hz), 7.34 (d, 2H, ArH, J = $6.8 \mathrm{~Hz}), 6.62$ (t, 2H, ArH, J = 7.8 Hz), $5.12(\mathrm{~s}, 1 \mathrm{H},-\mathrm{NH})$. ES-MS $\left(\mathrm{CH}_{3} \mathrm{OH}\right): \mathrm{m} / \mathrm{z}: 695.1\left([\mathrm{M}-\mathrm{H}]{ }^{-}\right), 727.1([\mathrm{M}+$ $\left.\left.\mathrm{CH}_{3} \mathrm{OH}-\mathrm{H}\right]^{-}\right)$. IR (KBr disk): $v\left(\mathrm{~cm}^{-1}\right)=3401.6(\mathrm{~N}-\mathrm{H}), 2982.9,3077.2(\mathrm{~m}, \mathrm{C}=\mathrm{C}-\mathrm{H}), 1725.7$ (vs, HC=N), 1609.4 (vs, C=O), $1314.5\left(\mathrm{~s},-\mathrm{CF}_{3}\right), 956.6(\mathrm{~s}, \mathrm{~V}=\mathrm{O}), 730.9(\mathrm{~m}, \mathrm{~V}-\mathrm{N})$. Conductance $\left(\Omega^{-1} \cdot \mathrm{cm}^{2} \cdot \mathrm{mol}^{-1}\right): 11.8$.

\subsection{DNA-Binding and Cleavage}

Absorption titration of the oxovanadium complexes in buffer 1 were performed using a fixed concentration of the oxovanadium complexes $\left(20 \mu \cdot \mathrm{mol} \cdot \mathrm{L}^{-1}\right)$ to which the DNA stock solutions were added. The oxovanadium-DNA solutions were incubated at room temperature for 3 mins before the absorption spectra were recorded. In order to further elucidate the binding strength of the complexes, the intrinsic binding constant $K_{b}$ with CT-DNA was obtained by monitoring the change in the absorbance of the ligand transfer band with increasing 
amounts of DNA. $K_{b}$ was then calculated using the following equation [25] [34] [35]:

$$
\frac{[\mathrm{DNA}]}{\varepsilon_{a}-\varepsilon_{f}}=\frac{[\mathrm{DNA}]}{\varepsilon_{b}-\varepsilon_{f}}+\frac{1}{K_{b}\left(\varepsilon_{b}-\varepsilon_{f}\right)}
$$

where [DNA] is the concentration of DNA in the base pairs, and $\varepsilon_{a}-\varepsilon_{f}$ and $\varepsilon_{b}$ refer to the corresponding apparent absorption coefficient Aobsd/[Vanadium], the extinction coefficient for the free oxovanadium complexes and the extinction coefficient for the oxovanadium complexes in the fully bound form, respectively. In plots of [DNA] $/\left(\varepsilon_{a}-\varepsilon_{f}\right)$ versus [DNA], $K_{b}$ is obtained by the ratio of the slope to the intercept.

Viscosity measurements were carried out with an Ubbelohde viscometer maintained at a constant temperature of $(28.0 \pm 0.1) \mathrm{C}$ in a thermostatic bath. Flow time was measured with a digital stopwatch, and each sample was measured five times to obtain the average flow time. Date are presented as $\left(\eta / \eta_{0}\right)^{1 / 3}$ versus binding ratio [36] [37], where $\eta$ is the viscosity of DNA in the presence of complexes while $\eta_{0}$ is the viscosity of DNA alone.

Thermal denaturation studies were carried out with Shimadzu UV-3101 PC spectrophotometer equipped with a Peltier temperature-controlling programmer $\left( \pm 0.1^{\circ} \mathrm{C}\right)$. The melting curves were obtained by measuring the absorbance at $260 \mathrm{~nm}$ for solutions of CT-DNA $\left(80 \mu \cdot \mathrm{mol} \cdot \mathrm{L}^{-1}\right)$ in the absence and presence of oxovanadium complex $\left[20 \mu \cdot \mathrm{mol} \cdot \mathrm{L}^{-1}\right]$ as a function of the temperature was scanned from $50^{\circ} \mathrm{C}$ to $90^{\circ} \mathrm{C}$ at a speed of $5^{\circ} \mathrm{C} \mathrm{min}^{-1}$. The melting temperature $\left(\mathrm{T}_{\mathrm{m}}\right)$ was taken as the mid-point of the hyperchromic transition.

The photoinduced cleavage activity of supercoiled pBR322 DNA by the oxovanadium complexes was studied by performing agarose gel electrophoresis experiment, pBR322 DNA $(0.1 \mu \mathrm{g})$ was treated with the complexes in buffer 2 in different concentrations, and the solutions were incubated at $37^{\circ} \mathrm{C}$ in the incubator for $1 \mathrm{~h}$. The samples were analyzed by electrophoresis for $2 \mathrm{~h}$ at $90 \mathrm{~V}$ in tris-boric buffer containing $0.8 \%$ agarose gel. The gel was stained with $0.1 \mu \mathrm{L} / \mathrm{ml}$ DuRed nucleic acid gel stain and photographed under UV light on an Alpha Innotech IS-5500 fluorescence chemiluminescence and visible imaging system [38] [39].

\section{Results and Discussion}

\subsection{Synthesis and Characterization}

The Schiff base ligand was prepared by a reaction of salicylaldehyde with N-Aminophthalimide in the appropriate mole ratios using absolute ethanol as solvent [28]. The oxovanadium complexes 1-3 were obtained by refluxing of corresponding Schiff bases, $\mathrm{VOSO}_{4} \cdot \mathrm{xH}_{2} \mathrm{O}$ and phenanthroline-based ligand in absolute methanol. The desired complexes were purified by recrystallization.

According to the IR spectra of phenanthroline-based ligands show absorption at ca. $3400 \mathrm{~cm}^{-1}$ (imidazole $\mathrm{N}-\mathrm{H}), 3065$ - $3078 \mathrm{~cm}^{-1}$ (C=C-H), 1483-1608 $\mathrm{cm}^{-1}$ (C=C), 1312-1326 $\mathrm{cm}^{-1}$ (C-F), respectively. In parallel, IR spectra absorption of complexes 1-3 observed at 3401-3425 cm $\mathrm{cm}^{-1}$ for (imidazole $\mathrm{N}-\mathrm{H}$ ), $2982-3077 \mathrm{~cm}^{-1}$ for $(\mathrm{C}=\mathrm{C}-\mathrm{H}), 1607-1725 \mathrm{~cm}^{-1}$ for $(\mathrm{C}=\mathrm{O})$ and $(-\mathrm{CH}=\mathrm{N}), 1312-1314 \mathrm{~cm}^{-1}$ for $\left(-\mathrm{CF}_{3}\right), 713-730 \mathrm{~cm}^{-1}$ for $(\mathrm{V}-\mathrm{N})$, respectively. The strong (VO) band at $956-974 \mathrm{~cm}^{-1}$ could be cleared identified for the formulation of the complex.

Electronic spectra of complexes 1-3 show an intense band at ca. $272 \mathrm{~nm}$ assignable to $\pi-\pi^{*}$ transition of aromatic rings of phenanthroline-based ligands [15] [25]. Bands in the UV-vis region (320 - $350 \mathrm{~nm}$ ) are assignable to intraligand transitions of the Schiff base. Five- and six-coordination complexes of oxovanadium (IV) are usually square pyramidal/trigonal bipyramidal and distorted octahedral, respectively [40] [41]. From the above spectral data, the Schiff base bonded through the phenolate oxygen, imine nitrogen, and carbonyl oxygen leaving the carbonyl as a pendant group. This implies that these complexes bear the central V (IV) atom in a squarepyramidal geometry.

In the ${ }^{1} \mathrm{H}$ NMR spectra of phenanthroline-based ligands showed peaks of aromatic hydrogen ( $\left.\mathrm{ArH}\right)$, imidazole secondary amine $(\mathrm{NH})$ proton. However, in the ${ }^{1} \mathrm{H}$ NMR spectra of complexes, the peaks of imine $(\mathrm{CH}=\mathrm{N})$ proton were observed, which affirmed that the Schiff base ligand was coordinated to vanadium.

In the ES-MS spectra of $\mathrm{CF}_{3} \mathrm{PIP}, \mathrm{m}-\mathrm{CF}_{3} \mathrm{PIP}$ and $\mathrm{p}-\mathrm{CF}_{3} \mathrm{PIP}$ showed peaks at $\mathrm{m} / \mathrm{z} 365\left([\mathrm{M}+\mathrm{H}]^{+}\right)$and $387([\mathrm{M}+$ $\left.\mathrm{Na}]^{+}\right)$. The molecular ion peaks of three complexes at $\mathrm{m} / \mathrm{z} 695\left([\mathrm{M}-\mathrm{H}]^{-}\right)$and $727\left(\left[\mathrm{M}+\mathrm{CH}_{3} \mathrm{OH}-\mathrm{H}\right]\right)$ ). Elemental analysis, ES-MS, IR and ${ }^{1} \mathrm{H}$ NMR data of all the compounds are in good agreement with the expected structures.

The molar conductance values of phenanthroline-based ligands and complexes 1-3 in DMF $\left(1 \mathrm{~m} \cdot \mathrm{mol} \cdot \mathrm{L}^{-1}\right)$ are shown in Table 1. The conductive properties indicates that both ligands $\mathbf{L}_{1}-\mathbf{L}_{3}$ and oxovanadium complexes 1-3 are nonelectrolytes. 
Table 1. Molar conductivity data of oxovanadium complexes and the ligands.

\begin{tabular}{cc}
\hline Compounds & $\Omega^{-1} \cdot \mathrm{cm}^{2} \cdot \mathrm{mol}^{-1}$ \\
\hline $\mathrm{CF}_{3} \mathrm{PIP}$ & 9.2 \\
$\mathrm{~m}-\mathrm{CF}_{3} \mathrm{PIP}$ & 9.6 \\
$\mathrm{p}-\mathrm{CF}_{3} \mathrm{PIP}$ & 8.6 \\
$\mathrm{VO}(\mathrm{Hbid})\left(\mathrm{CF}_{3} \mathrm{PIP}\right)$ & 10.7 \\
$\mathrm{VO}(\mathrm{Hbid})\left(\mathrm{m}-\mathrm{CF}_{3} \mathrm{PIP}\right)$ & 9.7 \\
$\mathrm{VO}(\mathrm{Hbid})\left(\mathrm{p}-\mathrm{CF}_{3} \mathrm{PIP}\right)$ & 11.8 \\
\hline
\end{tabular}

\subsection{DNA-Binding Studies}

\subsubsection{Electronic Absorption Titration}

For the purpose of evaluating the capacity of oxovanadium complexes interacting with CT-DNA, the electronic spectra of complexes 1, 2 and 3 in the absence and presence of increasing amounts of CT-DNA are shown in Figure 1. As the CT-DNA concentration is increased, obvious hypochromism as well as a certain degree of bathochromism for the three oxovanadium complexes can be observed in the ultraviolet titration process at ca. 272 $\mathrm{nm}$, which is attributed to $\pi \rightarrow \pi^{*}$. The hypochromism and bathochromism shift for $\mathbf{1}$ at $272 \mathrm{~nm}$ are $28.72 \%$ and 2 $\mathrm{nm}$, respectively. In contrast, the hypochromism and bathochromism of complexes 2 and 3 are $20.93 \%, 1 \mathrm{~nm}$ and 30.36\%, $2.5 \mathrm{~nm}$, respectively. According to previously reported results [14] [23]-[25], the UV-Vis spectral characteristics suggest that complexes 1-3 interact with CT-DNA most likely through a mode that involves a stacking interaction between the aromatic chromophore and the base pairs of DNA.

In order to elucidate the binding strengths of these complexes, the intrinsic binding constant $K_{b}$ were calculated by monitoring the changes of absorbance in the ligand transfer bands with increasing amounts of CT-DNA. The $K_{b}$ values of complexes 1-3 were calculated as $7.40 \times 10^{4}\left(\mathrm{~mol} \cdot \mathrm{L}^{-1}\right)^{-1}, 5.42 \times 10^{4}\left(\mathrm{~mol} \cdot \mathrm{L}^{-1}\right)^{-1}$ and $1.25 \times 10^{5}$ $\left(\mathrm{mol} \cdot \mathrm{L}^{-1}\right)^{-1}$, respectively, indicating that they strongly interact with DNA by intercalation. And the DNA-binding activities of these three complexes are higher than that of reported mononuclear oxovanadium complexes VO(SAA)(phen) $\left(4.50 \times 10^{4} \mathrm{M}^{-1}\right)$ and VO(MOSAA) (phen) $\left(2.95 \times 10^{4} \mathrm{M}^{-1}\right)$ [25], under our experimental conditions. The value of $K_{b}$ increases in the order $2<\mathbf{1}<\mathbf{3}$, this may due to the substituents of trifluoromethyl phenyl introduced on the phenanthroline ring of complexes 1-3, which may intercalate into base pairs of CT-DNA in complexes 1-3 will be altered, resulting in higher $K_{b}$. Meanwhile, the presence of an - $\mathrm{CF}_{3}$ group on the aromatic moieties, which acts as an electron-drawing substituent on the intercalative ligand and thus gives stronger stacking interactions with DNA for complexes 1-3. And the electronic effects of substituted group at the different locations introduced on the aromatic ring of phenanthroline-based ligands may make differences in the DNA-binding affinities. The results also indicates an $-\mathrm{CF}_{3}$ group substituted on the para-position of the aromatic exhibits stronger DNA-binding affinity than substituted on the ortho-position and meta-position.

\subsubsection{Fluorescence Spectroscopic Studies}

The interaction of the complexes $\left(20 \mu \cdot \mathrm{mol} \cdot \mathrm{L}^{-1}\right)$ with CT-DNA was investigated using fluorescence emission titration experiment in the Tris buffer 1 at room temperature. The emission spectra of complexes 1, 2 and $\mathbf{3}$ in the absence and presence of CT-DNA exhibit luminescence in Tris buffer, with a maxima appearing at $442 \mathrm{~nm}, 443$ $\mathrm{nm}$ and $440 \mathrm{~nm}$ respectively, which are shown in Figure 2. With increasing concentrations of CT-DNA, the emission intensities of complexes $\mathbf{1 - 3}$ grow to around by about $0.26,0.19$, and 0.36 times larger than those in the absence of CT-DNA and saturates at a [DNA]/[V] ratio of 20:1. The enhancement of emission intensity is indicative of binding of the complexes to the hydrophobic pocket of DNA, since the hydrophobic environment inside the DNA helix reduces the accessibility of water molecules to the complex and the complex mobility is restricted at the binding site, leading to decrease of the vibrational modes of relaxation [42] [43]. In addition, it also shows that $\mathbf{3}$ interacts with DNA more strongly than both $\mathbf{1}$ and 2, consistent with the UV-vis absorption titration spectra results.

\subsubsection{Viscosity Measurements}

To further clarify the nature of the binding interaction between both oxovanadium complexes and DNA in the absence of X-ray structural data or NMR spectra, viscosity measurements that are regarded as the least contro- 
versial and the most rigorous means of testing the binding model of DNA in solution [44]. It is well-known that a classical intercalation model leads to an apparent increase in viscosity of DNA solution due to base-pairs are pushed apart and hence an increase in overall DNA length [45]. In contrast, a partial, non-classical intercalation of compounds could bend (or kink) the DNA helix and reduce its effective length and, concomitantly, its viscosity [46].

The effects of complexes 1, 2 and $\mathbf{3}$ on the viscosity of CT-DNA are shown in Figure 3. As can be seen in Figure 3, with amounts of the complexes increasing, the relative viscosity of DNA increases continuously to some extend. The results thus provide strong evidence for the interaction of complexes $\mathbf{1}, \mathbf{2}$ and $\mathbf{3}$ with CT-DNA by intercalation modes. Moreover, the increasing degree of viscosity is $\mathbf{2}<\mathbf{1}<\mathbf{3}$, which is consistent with electronic absorption spectra data, supporting the conclusion that complexes 1-3 interact with DNA by intercalation modes.

\subsubsection{Thermal Denaturation Studies}

DNA melting experiments are generally applied to investigate the extent of intercalation, which were carried out by monitoring the intensity of DNA bases at $260 \mathrm{~nm}$ at different temperatures, both in the absence and presence of oxovanadium complexes. Thermal behaviors of DNA in the presence of compounds can give insight into their conformational changes when the temperature is raised and offer information about the interaction strength of complexes with DNA. As a rule, with the temperature in the solution rising, the double-stranded DNA will gradually dissociate to single strands and generate a hyperchromic effect on absorption spectra of DNA bases. Thus, the melting temperature $T_{m}$, which is defined as the temperature where half of the total base pairs are unbounded, is usually introduced. Generally, $\mathrm{T}_{\mathrm{m}}$ will increase considerable when intercalative binding occurs, since intercalation of the complexes into DNA base pairs causes stabilization of base stacking and hence raises the melting temperature of the double-stranded DNA [11] [24] [25].

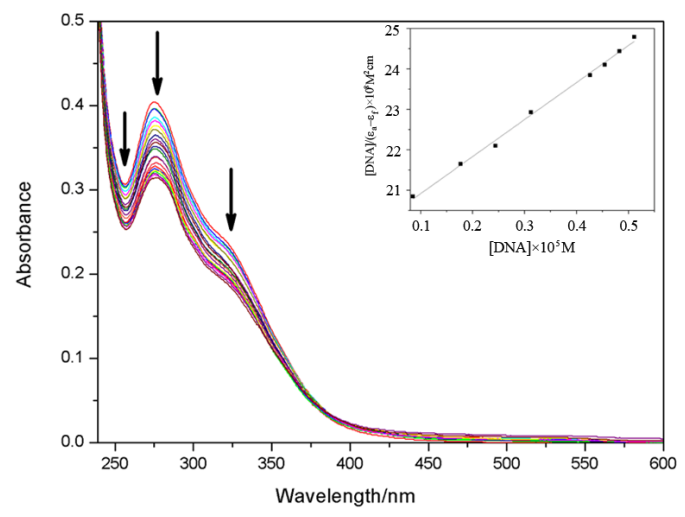

(a)

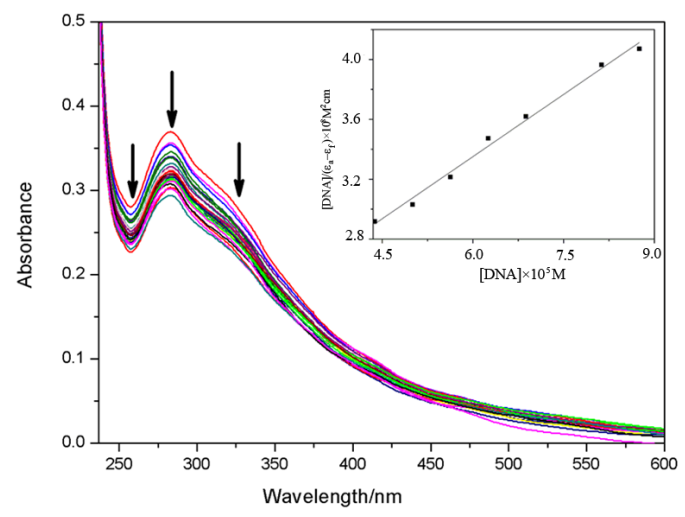

(b)

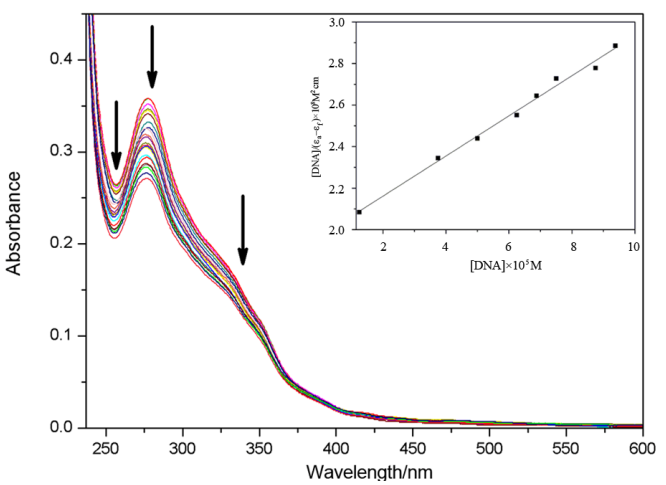

(c)

Figure 1. Absorption spectral of the complexes 1 (a), 2 (b) and 3 (c) in Tris-HCl buffer 1 upon increasing amounts of CT-DNA. [V] $=20 \mu \mathrm{M}$, [DNA] $=(0-100) \mu \mathrm{M}$. Arrow shows the decreasing absorbance upon increasing CT-DNA concentrations. Insert: Plots of [DNA]/( $\left.\varepsilon_{\mathrm{a}}-\varepsilon_{\mathrm{f}}\right)$ versus [DNA] for the titration of [V] with CT-DNA. 


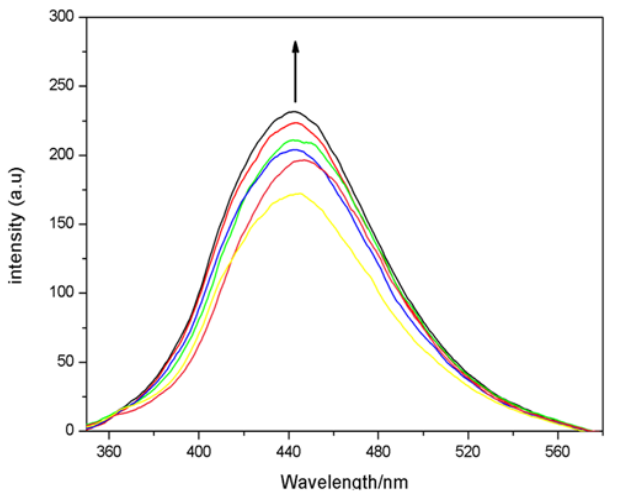

(a)

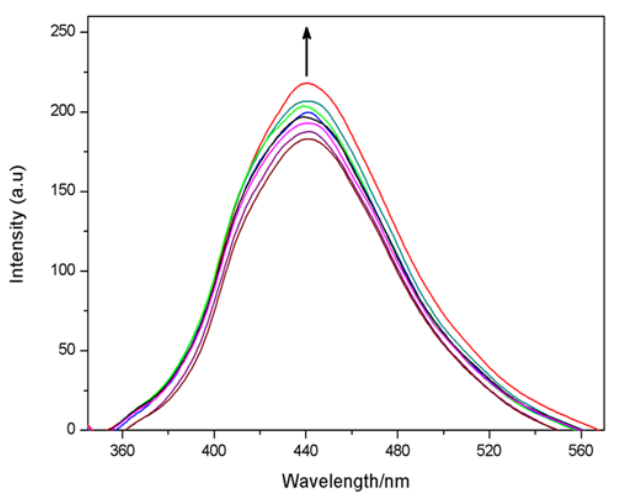

(b)

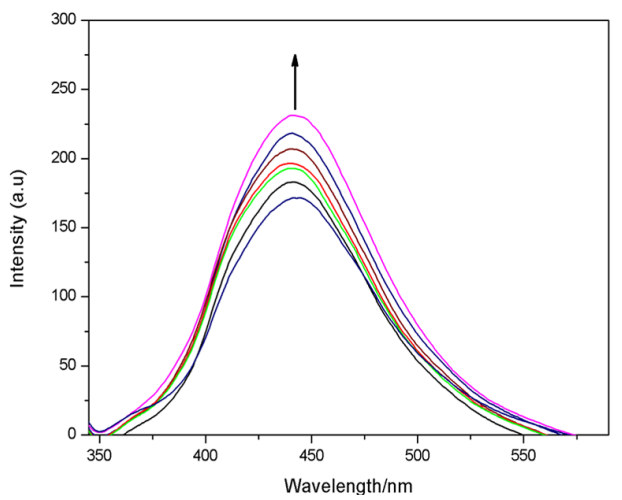

(c)

Figure 2. Emission spectra of $\mathbf{1}$ (a), 2 (b) and $\mathbf{3}$ (c) in Tris-HCl buffer 1 in the absence and presence of CT-DNA. [V] $=20 \mu \cdot \mathrm{mol} \cdot \mathrm{L}^{-1}$. Arrows show the increasing intensity with increasing concentrations of DNA.

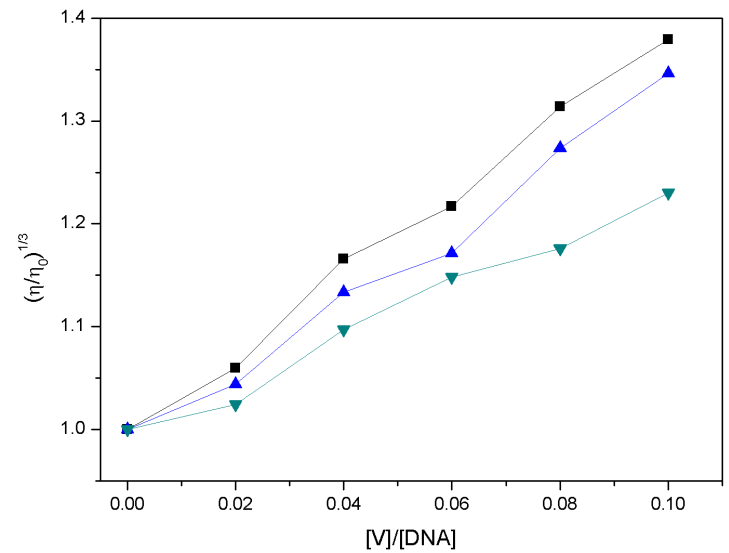

Figure 3. Effect of increasing amounts of complexes $\mathbf{1}(\boldsymbol{\Delta}), \mathbf{2}(\boldsymbol{\nabla})$ and $\mathbf{3}(\boldsymbol{\nabla})$ on the relative viscosity of CT-DNA at $(28.0 \pm 0.1)^{\circ} \mathrm{C}$, [DNA] $=0.2 \mathrm{~m} \cdot \mathrm{mol} \cdot \mathrm{L}^{-1}$.

The melting curves of CT-DNA in the absence and presence of complexes 1-3 are shown in Figure 4; As shown in Figure 4, The $\mathrm{T}_{\mathrm{m}}$ of CT-DNA in the absence of the complexes is $62.2^{\circ} \mathrm{C} \pm 0.2^{\circ} \mathrm{C}$, meanwhile, when the complexes at a concentration ratio [V]/[DNA] of 1:4, we can observe that $\mathrm{T}_{\mathrm{m}}$ values in the presence of the complexes 1,2 and 3 are $68.3^{\circ} \mathrm{C} \pm 0.2^{\circ} \mathrm{C}, 65.3^{\circ} \mathrm{C} \pm 0.2^{\circ} \mathrm{C}, 69.2^{\circ} \mathrm{C} \pm 0.2^{\circ} \mathrm{C}$, respectively. A comparison of the $\Delta \mathrm{T}_{\mathrm{m}}$ values of the complexes $\left(6.1^{\circ} \mathrm{C}, 3.1^{\circ} \mathrm{C}\right.$ and $7.0^{\circ} \mathrm{C}$ for $\mathbf{1}, 2$, and 3 , respectively) was agreement with those classical intercalators [47] [48], which provided strong evidence for their binding with DNA by intercalation.

The experimental data reveals that complexes in collaboration with phenanthroline-substituted auxiliary li- 


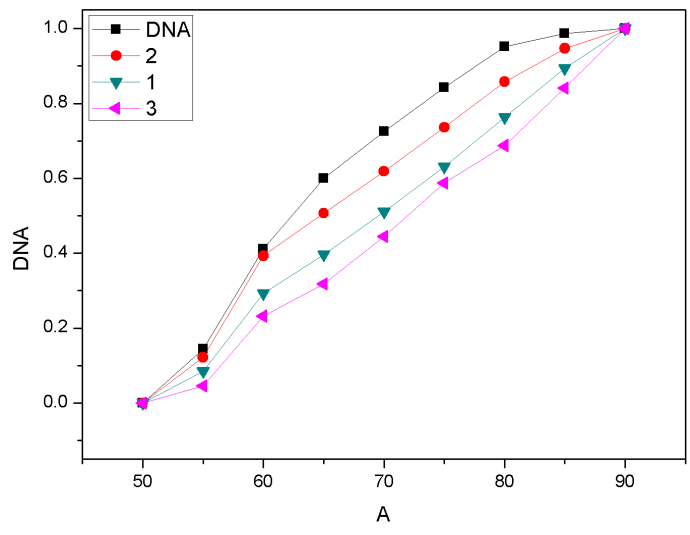

Figure 4. Thermal denaturation of CT-DNA in the absence and presence of complexes 1, 2 and 3, [V] $=20 \mu \mathrm{M},[\mathrm{DNA}]=80 \mu \mathrm{M}$.

gands exhibit appreciable DNA intercalative activities, in addition, complex $\mathbf{3}$ showed a larger $\Delta \mathrm{T}_{\mathrm{m}}$, indicating that 3 exhibits stronger DNA-binding affinity when interacting with DNA, in conformity with the electronic absorption titration.

\subsection{Photocleavage Studies}

The interaction mode between these oxovanadium complexes and plasmid DNA were further investigated by agarose gel electrophoresis experiments. When circular plasmid DNA is subject to electrophoresis, relatively fast migration will be observed for the intact supercoiled form (form I). If scission occurs on one strand (nicking), the supercoil will relax to generate a slower moving open circular form (form II). If both strands are cleaved, a linear form (form III) migrating between form I and II will be generated [49] [50].

As is shown both in Figure 5 and Figure 6, it is clear to figure out the cleavage activity of plasmid pBR322 DNA after incubation with different concentrations of oxovanadium complexes at $37^{\circ} \mathrm{C}$ for $1 \mathrm{~h}$ at dark condition. The nicked form II can barely observed for $\mathrm{H}_{2} \mathrm{O}_{2}$ alone in the absence of the complexes (lane 2 in Figure 5 and Figure 6, respectively). Nevertheless, in the presence of complexes $\mathbf{1}, 2$ and 3 with $30 \mathrm{~m} \cdot \mathrm{mol} \cdot \mathrm{L}^{-1} \mathrm{H}_{2} \mathrm{O}_{2}$, apparent cleavage of pBR322 DNA observed from the formation of form II, and cleaving activity tends to increase gradually with the concentration of the complexes increase from $15 \mu \cdot \mathrm{mol} \cdot \mathrm{L}^{-1}$ to $60 \mu \cdot \mathrm{mol} \cdot \mathrm{L}^{-1}$ (lane 3,4 and 5 in Figure 5 and Figure 6). Furthermore, under the same conditions with lane 4 , addition of $0.02 \mathrm{~mol} \cdot \mathrm{L}^{-1} \mathrm{~L}-\mathrm{Histi}-$ dine works as a singlet oxygen quencher (lane 6, lane 11 in Figure 5 and Figure 6, respectively) slightly inhibits the cleavage of DNA. Meanwhile, no cleavage of plasmid DNA occurred in the presence of hydroxyl radical scavenger DMSO (lane 7, lane 12 in Figure 5 and Figure 6, respectively), suggesting that $\cdot \mathrm{OH}$ radicals is likely to be the reactive species on account of the oxidation of $\mathrm{VO}^{2+}$ in the presence of $\mathrm{H}_{2} \mathrm{O}_{2}$ for the cleavage reaction [51]. Under comparative experimental conditions, a linear form (form III) (lane 4, lane 5 in Figure 6) can be observed when the concentration of complex 3 reaches to $30 \mu \cdot \mathrm{mol} \cdot \mathrm{L}^{-1}$ and $60 \mu \cdot \mathrm{mol} \cdot \mathrm{L}^{-1}$, respectively, implying the photocleavage ability of complex $\mathbf{3}$ is stronger than that of complexes $\mathbf{1}$ and $\mathbf{2}$, follows the order of $\mathbf{3}>\mathbf{1}>\mathbf{2}$. The results are actually consistent with the degree of their intrinsic binding constant $\left(K_{b}\right)$, indicating that the electrochemical characteristics of phenanroline-based auxiliary ligands as well as the existence of substituted strong electronic-withdrawing group $\left(-\mathrm{CF}_{3}\right)$ at the different locations introduced on the aromatic ring of phenanroline-based ligands plays an important role in the DNA-binding affinity.

\section{Conclusion}

In this paper, three novel Schiff base oxovanadium complexes, [VO(Hbid) $\left.\left(\mathrm{CF}_{3} \mathrm{PIP}\right)\right](\mathbf{1})$, [VO(Hbid)(m-CF $\left.\left.\mathrm{PIP}_{3}\right)\right]$ (2), [VO(Hbid)(p-CF $\left.\left.{ }_{3} \mathrm{PIP}\right)\right]$ (3) have been synthesized and characterized by EA, ES-MS, IR, ${ }^{1} \mathrm{H}$ NMR and molar conductance. Their DNA-binding activities with CT-DNA were evaluated using UV-Vis titration, viscosity measurements and thermal denaturation. These three oxovanadium complexes interact with CT-DNA by intercalation modes. Their photocleavage activities of supercoiled plasmid DNA were investigated in the presence of $\mathrm{H}_{2} \mathrm{O}_{2}$ probably via generating hydroxyl radical, the results also show efficiently oxidative cleavage activities, in 


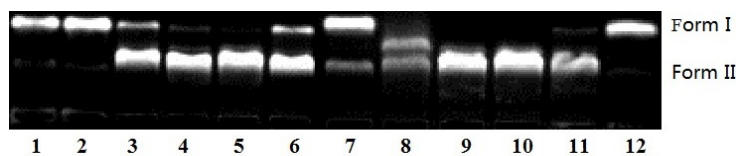

Figure 5. Cleavage of pBR322 DNA by complexes 1 and $2\left(15-60 \mu \cdot \mathrm{mol} \cdot \mathrm{L}^{-1}\right)$ in the absence and presence of $\mathrm{H}_{2} \mathrm{O}_{2}$ (30 $\mathrm{m} \cdot \mathrm{mol} \cdot \mathrm{L}^{-1}$ ) in buffer $2\left(\mathrm{pH}\right.$ 7.2).lane 1, DNA control; lane 2, DNA $+\mathrm{H}_{2} \mathrm{O}_{2}$; lane 3, DNA $+1\left(15 \mu \cdot \mathrm{mol} \cdot \mathrm{L}^{-1}\right)+$ $\mathrm{H}_{2} \mathrm{O}_{2}$; lane 4, DNA + $1\left(30 \mu \cdot \mathrm{mol} \cdot \mathrm{L}^{-1}\right)+\mathrm{H}_{2} \mathrm{O}_{2}$; lane 5, DNA + $1\left(60 \mu \cdot \mathrm{mol} \cdot \mathrm{L}^{-1}\right)+\mathrm{H}_{2} \mathrm{O}_{2}$; lane 6, DNA + $\mathbf{1}(30 \mu \cdot \mathrm{mol} \cdot$ $\left.\mathrm{L}^{-1}\right)+\mathrm{H}_{2} \mathrm{O}_{2}+\mathrm{L}-H i s t i d i n e\left(0.02 \mathrm{~mol} \cdot \mathrm{L}^{-1}\right)$; lane 7 , DNA + $1\left(30 \mu \cdot \mathrm{mol} \cdot \mathrm{L}^{-1}\right)+\mathrm{H}_{2} \mathrm{O}_{2}+$ DMSO $(2 \mu \cdot \mathrm{L})$; lane 8, DNA + 2 $\left(15 \mu \cdot \mathrm{mol} \cdot \mathrm{L}^{-1}\right)+\mathrm{H}_{2} \mathrm{O}_{2}$; lane 9, DNA $+2\left(30 \mu \cdot \mathrm{mol} \cdot \mathrm{L}^{-1}\right)+\mathrm{H}_{2} \mathrm{O}_{2}$; lane 10, DNA $+2\left(60 \mu \cdot \mathrm{mol} \cdot \mathrm{L}^{-1}\right)+\mathrm{H}_{2} \mathrm{O}_{2}$; lane 11, DNA + $2\left(30 \mu \cdot \mathrm{mol} \cdot \mathrm{L}^{-1}\right)+\mathrm{H}_{2} \mathrm{O}_{2}+\mathrm{L}$-Histidine $\left(0.02 \mathrm{~mol} \cdot \mathrm{L}^{-1}\right)$; lane 12 , DNA $+2\left(30 \mu \cdot \mathrm{mol} \cdot \mathrm{L}^{-1}\right)+\mathrm{H}_{2} \mathrm{O}_{2}+\mathrm{DMSO}(2$ $\mu \cdot \mathrm{L})$.

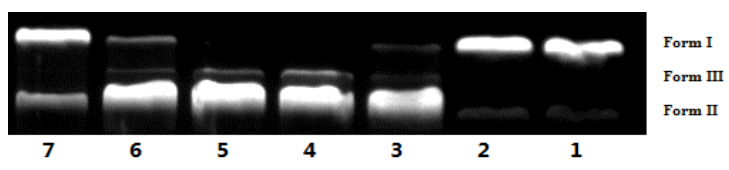

Figure 6. Cleavage of pBR322 DNA by complex $3\left(15-60 \mu \cdot \mathrm{mol} \cdot \mathrm{L}^{-1}\right)$ in the absence and presence of $\mathrm{H}_{2} \mathrm{O}_{2}(30 \mathrm{~m}$. $\mathrm{mol} \cdot \mathrm{L}^{-1}$ ) in buffer 2 (pH 7.2). Lane 1, DNA control; lane 2, DNA $+\mathrm{H}_{2} \mathrm{O}_{2}$; lane 3, DNA + $3\left(15 \mu \cdot \mathrm{mol}^{-1} \cdot \mathrm{L}^{-1}\right)+\mathrm{H}_{2} \mathrm{O}_{2}$; lane 4, DNA + $3\left(30 \mu \cdot \mathrm{mol} \cdot \mathrm{L}^{-1}\right)+\mathrm{H}_{2} \mathrm{O}_{2}$; lane 5, DNA + $3\left(60 \mu \cdot \mathrm{mol} \cdot \mathrm{L}^{-1}\right)+\mathrm{H}_{2} \mathrm{O}_{2}$; lane 6, DNA + $3\left(30 \mu \cdot \mathrm{mol} \cdot \mathrm{L}^{-1}\right)+$ $\mathrm{H}_{2} \mathrm{O}_{2}+$ L-Histidine $\left(0.02 \mathrm{~mol} \cdot \mathrm{L}^{-1}\right)$; lane 7 , DNA $+3\left(30 \mu \cdot \mathrm{mol} \cdot \mathrm{L}^{-1}\right)+\mathrm{H}_{2} \mathrm{O}_{2}+$ DMSO $(2 \mu \cdot \mathrm{L})$.

conformity with DNA-binding behaviors of the complexes. In addition, complex 3 exhibits a higher DNAbinding affinity in contrast to complexes 1 and 2, indicating that the electrochemical characteristics of phenanroline plane and the existence of substituted strong electronic-withdrawing group $\left(-\mathrm{CF}_{3}\right)$ at the different locations introduced on the aromatic ring of phenanroline-based ligands plays an important role in the DNA-binding affinity.

\section{Acknowledgements}

We gratefully acknowledge financial support for this work by the Science and technology Research Project of Guangdong Province (No.2012B031800431), P. R. China and Cultivation of Natural Science Joint Fund of the First Affiliated Hospital and the Scientific \& Technical Department of Guangdong Pharmaceutical University (No. 2014-36).

\section{References}

[1] Chen, Z.F., Liu, Y.C., Huang, K.B. and Liang, H. (2013) Alkaloid-Metal Based Anticancer Agents. Current Topics in Medicinal Chemistry (Sharjah, United Arab Emirates), 13, 2104-2115. http://dx.doi.org/10.2174/15680266113139990146

[2] Rafique, S., Idrees, M., Nasim, A., Akbar, H. and Athar, A. (2010) Transition Metal Complexes as Potential Therapeutic Agents. Biotechnology and Molecular Biology Reviews, 5, 38-45.

[3] Gu, J. and Codd, R. (2012) Copper(II)-Based Metal Affinity Chromatography for the Isolation of the Anticancer Agent Bleomycin from Streptomyces verticillus Culture. Journal of Inorganic Biochemistry, 115, 198-203. http://dx.doi.org/10.1016/j.jinorgbio.2012.01.015

[4] Leon, I. E., Porro, V., Di, V.A.L., Naso, L.G., Williams, P.A.M., Bollati-Fogolin, M. and Etcheverry, S.B. (2014) Antiproliferative and Apoptosis-Inducing Activity of an Oxidovanadium(IV) Complex with the Flavonoid Silibinin against Osteosarcoma Cells. Journal of Biological Inorganic Chemistry, 19, 59-74. http://dx.doi.org/10.1007/s00775-013-1061-x

[5] Anupama, B. and Gyana Kumari, C. (2011) Synthesis, Characterization, DNA Binding and Antimicrobial Activity of 4-Amino Antipyrine Schiff Base Metal Complexes. Research Journal of Pharmaceutical, Biological and Chemical Sciences, 2, 140-159.

[6] Walmsley, R.S., Litwinski, C., Antunes, E., Hlangothi, P., Hosten, E., McCleland, C., Nyokong, T., Torto, N. and Tshentu, Z.R. (2013) Oxovanadium(IV)-Containing Poly(Styrene-co-4'-Ethenyl-2-Hydroxyphenylimidazole) Electrospun Nanofibers for the Catalytic Oxidation of Thioanisole. Journal of Molecular Catalysis A: Chemical, 379, 94-102. http://dx.doi.org/10.1016/j.molcata.2013.07.018

[7] Parihar, S., Jadeja, R.N. and Gupta, V.K. (2014) Novel Oxovanadium(IV) Complexes with 4-Acyl Pyrazolone Ligands: 
Synthesis, Crystal Structure and catalytic Activity towards the Oxidation of Benzylic Alcohols. RSC Advances, 4, 10295-10302. http://dx.doi.org/10.1039/c3ra46896h

[8] Sanna, D., Micera, G. and Garribba, E. (2013) Interaction of Insulin-Enhancing Vanadium Compounds with Human Serum holo-Transferrin. Inorganic Chemistry, 52, 11975-11985. http://dx.doi.org/10.1021/ic401716x

[9] Yamaguchi, T., Watanabe, S., Matsumura, Y., Tokuoka, Y. and Yokoyama, A. (2012) Synthesis of Oxovanadium Complexes and Their Apoptosis-Inducing Activity in Leukemia Cells. Chemical \& Pharmaceutical Bulletin, 60, 508512. http://dx.doi.org/10.1248/cpb.60.508

[10] Yamaguchi, T., Watanabe, S., Matsumura, Y., Tokuoka, Y. and Yokoyama, A. (2012) Oxovanadium Complexes with Quinoline and Pyridinone Ligands: Syntheses of the Complexes and Effect of Alkyl Chains on Their Apoptosis-Inducing Activity in Leukemia Cells. Bioorganic \& Medicinal Chemistry, 20, 3058-3064. http://dx.doi.org/10.1016/j.bmc.2012.02.063

[11] Liao, X.W., Pan, W.J., He, R.W., Guo, H.W., Ying, P. and Lu, J.Z. (2014) Unsymmetrical Oxovanadium Complexes Derived from Salicylaldehyde and Phenanthroline: Synthesis, DNA Interactions and Antitumor Activities. Chemical Biology \& Drug Design, 83, 367-378. http://dx.doi.org/10.1111/cbdd.12248

[12] Zhai, S.S., Guo, Q., Dong, J.F., Xu, T. and Li, L.Z. (2014) An Oxovanadium(IV) Complex of an L-Serine Schiff Base and 1,10-Phenanthroline: Synthesis, Crystal Structure, and DNA and Albumin-Binding Properties. Transition Metal Chemistry, 39, 271-280. http://dx.doi.org/10.1007/s11243-014-9800-6

[13] Sumrra, S.H. and Chohan, Z.H. (2013) In Vitro Antibacterial, Antifungal and Cytotoxic Activities of Some Triazole Schiff Bases and Their Oxovanadium(IV) Complexes. Journal of Enzyme Inhibition and Medicinal Chemistry, 28, 1291-1299. http://dx.doi.org/10.3109/14756366.2012.735666

[14] Liao, X.W., Lu, J.Z., Ying, P., Zhao, P., Bai, Y.L., Li, W.J. and Liu, M.P. (2013) DNA Binding, Antitumor Activities and Hydroxyl Radical Scavenging Properties of Novel Oxovanadium(IV) Complexes with Substituted Isoniazid. Journal of Biological Inorganic Chemistry, 18, 975-984. http://dx.doi.org/10.1007/s00775-013-1046-9

[15] Jing, B.Q., Dong, J.F., Li, J.H., Xu, T. and Li, L.Z. (2013) Synthesis, Crystal Structure and DNA Interaction of an Oxovanadium(IV) Complex Containing L-Valine Schiff Base and 1,10-Phenanthroline. Journal of Coordination Chemistry, 66, 520-529. http://dx.doi.org/10.1080/00958972.2013.763939

[16] Shiva, K.L. and Revanasiddappa, H.D. (2011) Synthesis, Characterization, Antimicrobial, DNA Binding and Oxidative Cleavage Activities of $\mathrm{Cu}(\mathrm{II})$ and $\mathrm{Co}(\mathrm{II})$ Complexes with 2-(2-Hydroxybenzylideneamino) Isoindoline-1, 3-Dione. Journal of Coordination Chemistry, 64, 699-714. http://dx.doi.org/10.1080/00958972.2011.554544

[17] Sugihara, H. and Hiratani, K. (1996) 1,10-Phenanthroline Derivatives as Ionophores for Alkali Metal Ions. Coordination Chemistry Reviews, 148, 285-299. http://dx.doi.org/10.1016/0010-8545(95)01178-1

[18] Sun, D.D., Wang, W.Z., Mao, J.W., Mei, W.J. and Liu, J. (2012) Imidazo [4,5-f][1,10] Phenanthroline Derivatives as Inhibitor of C-Myc Gene Expression in A549 Cells via NF- $\kappa$ B Pathway. Bioorganic \& Medicinal Chemistry Letters, 22, 102-105. http://dx.doi.org/10.1016/j.bmcl.2011.11.063

[19] Gomathi Sankareswari, V., Vinod, D., Mahalakshmi, A., Alamelu, M., Kumaresan, G., Ramaraj, R. and Rajagopal, S. (2014) Interaction of Oxovanadium(IV)-Salphen Complexes with Bovine Serum Albumin and Their Cytotoxicity against Cancer. Dalton Transactions, 43, 3260-3272. http://dx.doi.org/10.1039/c3dt52505h

[20] Naso, L.G., Lezama, L., Rojo, T., Etcheverry, S.B., Valcarcel, M., Roura, M., Salado, C., Ferrer, E.G. and Williams, P.A.M. (2013) Biological Evaluation of Morin and Its New Oxovanadium(IV) Complex as Antio-Xidant and Specific Anti-Cancer Agents. Chemico-Biological Interactions, 206, 289-301. http://dx.doi.org/10.1016/j.cbi.2013.10.006

[21] Zhang, Y.L., Wang, X.S., Fang, W., Cai, X.Y., Li, H.Z., Mao, J.W., Jin, X.B., Bai, Y.L. and Lu, J.Z. (2013) In Vitro Study of the Cytotoxicities of Two Mixed-Ligand Oxovanadium Complexes on Human Hepatoma Cells. Pharmazie, 68, 827-834.

[22] El-Asmy, A.A., Al-Gammal, O.A., Saad, D.A. and Ghazy, S.E. (2009) Synthesis, Characterization, Molecular Modeling and Eukaryotic DNA Degradation of 1-(3,4-Dihydroxybenzylidene) Thiosemicarbazide Complexes. Journal of Molecular Structure, 934, 9-22. http://dx.doi.org/10.1016/j.molstruc.2009.05.039

[23] Du, Y.f., Lu, J.Z., Guo, H.W., Jiang, J., Chao, P., Chen, F. and Pan, J.M. (2010) DNA Binding and Photocleavage Properties of Two Mixed-Ligand Oxovanadium Complexes. Transition Metal Chemistry, 35, 859-864. http://dx.doi.org/10.1007/s11243-010-9404-8

[24] Lu, J.Z., Guo, H.W., Zeng, X.D., Zhang, Y.L., Zhao, P., Jiang, J. and Zang, L.Q. (2012) Synthesis and Characterization of Unsymmetrical Oxidovanadium Complexes: DNA-Binding, Cleavage Studies and Antitumor Activities. Journal of Inorganic Biochemistry, 112, 39-48. http://dx.doi.org/10.1016/j.jinorgbio.2012.02.034

[25] Guo, H.W., Lu, J.Z., Ruan, Z.G., Zhang, Y.L., Liu, Y.J. Zang, L.Q. Jiang, J. and Huang, J.W. (2012) Synthesis, DNA-Binding, Cytotoxicity, and Cleavage Studies of Unsymmetrical Oxovanadium Complexes. Journal of Coordination Chemistry, 65, 191-204. http://dx.doi.org/10.1080/00958972.2011.645204 
[26] Jeslin Kanaga Inba, P., Annaraj, B., Thalamuthu, S. and Neelakantan, M.A. (2013) Cu(II), Ni(II), and Zn(II) Complexes of Salan-Type Ligand Containing Ester Groups: Synthesis, Characterization, Electrochemical Properties and in Vitro Biological Activities. Bioinorganic Chemistry and Applications, 2013, 439848-439860. http://dx.doi.org/10.1155/2013/439848

[27] Liu, Y.J., Li, Z.Z., Liang, Z.H., Yao, J.H. and Huang, H.L. (2011) Cytotoxicity, Apoptosis, Cellular Uptake, Cell Cycle Arrest, Photocleavage and Antioxidant Activity of 1,10-Phenanthroline Ruthenium(II) Complexes. DNA and Cell Biology, 30, 839-848. http://dx.doi.org/10.1089/dna.2011.1243

[28] Reichmann, M.E., Rice, C.A., Thomas, C.A. and Doty, P. (1954) A Further Examination of the Molecular Weight and Size of Deoxypentose Nucleic Acid. Journal of the American Chemical Society, 76, 3047-3053. http://dx.doi.org/10.1021/ja01640a067

[29] Wu, Q., Fan, C.D., Chen, T.F., Liu, C.R., Mei, W.J., Chen, S.D., Wang, B.G., Chen, Y.Y. and Zheng, W.J. (2013) Microwave-Assisted Synthesis of Arene Ruthenium(II) Complexes That Induce S-Phase Arrest in Cancer Cells by DNA Damage-Mediated p53 Phosphorylation. European Journal of Medicinal Chemistry, 63, 57-63. http://dx.doi.org/10.1016/j.ejmech.2013.01.037

[30] Cai, Z.B., Liu, L.F., Hong, Y.Q. and Zhou, M. (2013) Synthesis, Characterization and Nonlinear Optical Responses of Nickel(II) Complexes with Phenanthroline-Based Ligands. Journal of Coordination Chemistry, 66, 2388-2397. http://dx.doi.org/10.1080/00958972.2013.805322

[31] Tang, T.T., Tang, G.D., Kou, S.S., Zhao, J.Y., Culnane, L.F. and Zhang, Y. (2014) Experimental and DFT Studies on the Vibrational and Electronic Spectra of 2-(1H-Imidazo [4,5-f][1,10] Phenanthrolin-2-yl) phenol. Spectrochimica Acta, Part A: Molecular and Biomolecular Spectroscopy, 117, 144-151. http://dx.doi.org/10.1016/j.saa.2013.07.108

[32] Raman, N. and Selvan, A. (2011) DNA Interaction, Enhanced DNA Photocleavage, Electrochemistry, Thermal Investigation and Biopotential Properties of New Mixed-Ligand Complexes of Cu(II)/VO(IV) Based on Schiff Bases. Journal of Molecular Structure, 985, 173-183. http://dx.doi.org/10.1016/j.molstruc.2010.10.038

[33] Hazari, P.P., Pandey, A.K., Chaturvedi, S., Tiwari, A.K., Chandna, S., Dwarakanath, B.S. and Mishra, A.k. (2012) Synthesis of Oxovanadium(IV) Schiff Base Complexes Derived from C-Substituted Diamines and Pyridoxal-5-Phosphate as Antitumor Agents. Chemical Biology \& Drug Design, 79, 223-234. http://dx.doi.org/10.1111/j.1747-0285.2011.01265.X

[34] Li, C.Z., Wu, J.G., Wang, L.F., Min, R., Jia, N.Y. and Guo, J. (1999) Synthesis, Characterization and Antitumor Activity of Copper(II) Complex with Nicotinamido-4-Bis(2-Chloroethyl) Aminobenzaldimine. Journal of Inorganic Biochemistry, 73, 195-202. http://dx.doi.org/10.1016/S0162-0134(99)00005-7

[35] Zhao, P., Xu, L.C., Huang, J.W., Fu, B., Yu, H.C., Zhang, W.H., Chen, J., Yao, J.H. and Ji, L.N. (2008) DNA-Binding and Photocleavage Properties of Cationic Porphyrin-Anthraquinone Hybrids with Different Lengths of Links. Bioorganic Chemistry, 36, 278-287. http://dx.doi.org/10.1016/j.bioorg.2008.08.002

[36] Tabatabaee, M., Bordbar, M., Ghassemzadeh, M., Tahrir, M., Mehri Lighvan, Z. and Neumuller, B. (2013) Two New Neutral Copper(II) Complexes with Dipicolinic Acid and 3-Amino-1H-1,2,4-Triazole Formed under Different Reaction Conditions: Synthesis, Characterization, Molecular Structures and DNA-Binding Studies. European Journal of Medicinal Chemistry, 70, 364-371. http://dx.doi.org/10.1016/j.ejmech.2013.10.009

[37] Gabra, N.M., Mustafa, B., Kumar, Y.P., Shobha Devi, C., Shilpa, M., Reddy, K.L. and Satyanarayana, S. (2014) DNA-Binding and Cleavage, Cytotoxicity Properties of $\mathrm{Ru}(\mathrm{II})$ Complexes with 2-(4'-Chloro-Phenyl) Imidazo[4,5-f][1,10] Phenanthroline, Ligand and Their "Light Switch" on-off Effect. Medicinal Chemistry Research, 23, 224-235. http://dx.doi.org/10.1007/s00044-013-0617-1

[38] Hazari, P.P., Pandey, A.K., Chaturvedi, S., Tiwari, A.K., Chandna, S., Dwarakanath, B.S. and Mishra, A.K. (2012) Synthesis of Oxovanadium(IV) Schiff Base Complexes Derived from C-Substituted Diamines and Pyridoxal-5-Phosphate as Antitumor Agents. Chemical Biology \& Drug Design, 79, 223-234. http://dx.doi.org/10.1111/j.1747-0285.2011.01265.x

[39] Zhou, C.Q., Lin, Y.L., Chen, J.X. and Chen, W.H. (2012) Synergetic DNA-Cleaving Activities of the Metal Complexes of a Polyether-Tethered Pyrrole-Polyamide Dimer. Chemistry \& biodiversity, 9, 1125-1132. http://dx.doi.org/10.1002/cbdv.201100183

[40] Chen, C., Bai, F.Y., Zhang, R., Song, G., Shan, H., Xing, N. and Xing, Y.H. (2013) Synthesis, Structure and Catalytic Bromination of Supramolecular Oxovanadium Complexes Containing Oxalate. Journal of Coordination Chemistry, 66, 671-688. http://dx.doi.org/10.1080/00958972.2013.765561

[41] Bian, L., Li, L.Z., Zhang, Q.F., Dong, J.F., Xu, T., Li, J.H. and Kong, J.M. (2012) Synthesis, Crystal Structures, DNA Binding and Cleavage Studies of Two Oxovanadium(IV) Complexes of 1,10-Phenanthroline and Schiff Bases Derived from Tryptophan. Transition Metal Chemistry, 37, 783-790. http://dx.doi.org/10.1007/s11243-012-9653-9

[42] Lewis, N.A., Liu, F., Seymour, L., Magnusen, A. and Erves, T.R. (2012) Synthesis, Characterisation and Preliminary In Vitro Studies of Vanadium(IV) Complexes with a Schiff Base and Thiosemicarbazones as Mixed Ligands. Euro- 
pean Journal of Inorganic Chemistry, 2012, 664-677. http://dx.doi.org/10.1002/ejic.201100898

[43] Benitez, J., Becco, L., Correia, I., Leal, S.M. and Guiset, H. (2011) Vanadium Polypyridyl Compounds as Potential Antiparasitic and Antitumoral Agents: New Achievements. Journal of Inorganic Biochemistry, 105, 303-312. http://dx.doi.org/10.1016/j.jinorgbio.2010.11.001

[44] Mezo, G., Herenyi, L., Habdas, J., Majer, Z., Mysliwa-Kurdziel, B., Toth, K. and Csik, G. (2011) Syntheses and DNA Binding of New Cationic Porphyrin-Tetrapeptide Conjugates. Biophysical Chemistry, 155, 36-44. http://dx.doi.org/10.1016/j.bpc.2011.02.007

[45] Jang, Y.J., Yeo, G.Y., Park, B. and Kim, S.K. (2011) The Relationship between the Structures of Periphery Ligands and the DNA Binding Mode of [Ru(II) (1,10-Phenanthroline) $\left(\mathrm{L}_{1} \mathrm{~L}_{2}\right)$ Dipyrido[3,2-a:2',3'-c] Phenazine ${ }^{n+}\left(\mathrm{L}_{1}=\mathrm{Cl}_{\text {or }}\right.$ Pyridine and $\mathrm{L}_{2}=$ Pyridine, $n=1$, 2). Biophysical Chemistry, 158, 38-45. http://dx.doi.org/10.1016/j.bpc.2011.04.014

[46] Tan, D.J., He, Y., Qiu, L. and Zhang, Z.T. (2007) Studies on the Interactions of Sodium Chrysin-6-Sulfonate and Its Dinuclear Zinc, Tetra-Nuclear Calcium Complex with DNA. Chemical Research and Application, 19, 502-506.

[47] McCrate, A., Carlone, M., Nielsen, M. and Swavey, S. (2010) Anaerobic Photocleavage of Supercoiled DNA by a Ruthenium(II) Substituted Fluorinated Porphyrin. Inorganic Chemistry Communications, 13, 537-539. http://dx.doi.org/10.1016/j.inoche.2010.01.031

[48] Surendra, D.C., Siva Kumar, V., John Venison, S., Vetha Potheher, I. and Rajalaxmi Subahashini, D. (2013) Synthesis, Structural Characterisation, Bio-Potential Efficiency and DNA Cleavage Applications of Nicotinamide Metal Complexes. Journal of Molecular Structure, 1040, 192-205. http://dx.doi.org/10.1016/j.molstruc.2013.02.019

[49] Li, H.J., Bo, H.B., Wang, J.Q., Shao, H.W. and Huang, S.L. (2011) Separation of Supercoiled from Open Circular Forms of Plasmid DNA and Biological Activity Detection. Cytotechnology, 63, 7-12. http://dx.doi.org/10.1007/s10616-010-9322-9

[50] Nejedly, K., Sykorova, E., Diekmann, S. and Paleeek, E. (1998) Analysis of a Curved DNA Constructed from Alternating $\mathrm{dA}_{\mathrm{n}}: \mathrm{dT}_{\mathrm{n}}$-Tracts in Linear and Supercoiled Form by High Resolution Chemical Probing. Biophysical Chemistry, 73, 205-216. http://dx.doi.org/10.1016/S0301-4622(98)00145-8

[51] Benitez, J., Guggeri, L., Tomaz, I., Pessoa, J.C., Moreno, V., Lorenzo, J., Aviles, F.X., Garat, B. and Gambino, D. (2009) A Novel Vanadyl Complex with a Polypyridyl DNA Intercalator as Ligand: A Potential Anti-Protozoa and Anti-Tumor Agent. Journal of Inorganic Biochemistry, 103, 1386-1394. http://dx.doi.org/10.1016/j.jinorgbio.2009.07.013 
Scientific Research Publishing (SCIRP) is one of the largest Open Access journal publishers. It is currently publishing more than 200 open access, online, peer-reviewed journals covering a wide range of academic disciplines. SCIRP serves the worldwide academic communities and contributes to the progress and application of science with its publication.

Other selected journals from SCIRP are listed as below. Submit your manuscript to us via either submit@scirp.org or Online Submission Portal.
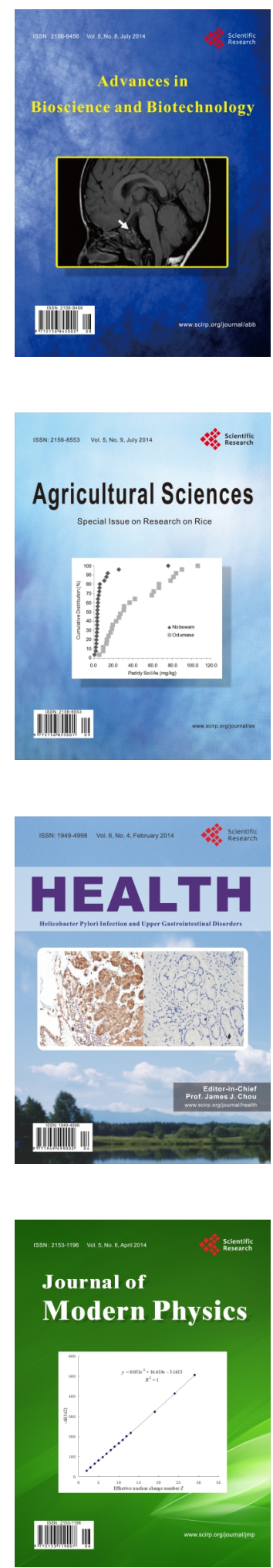
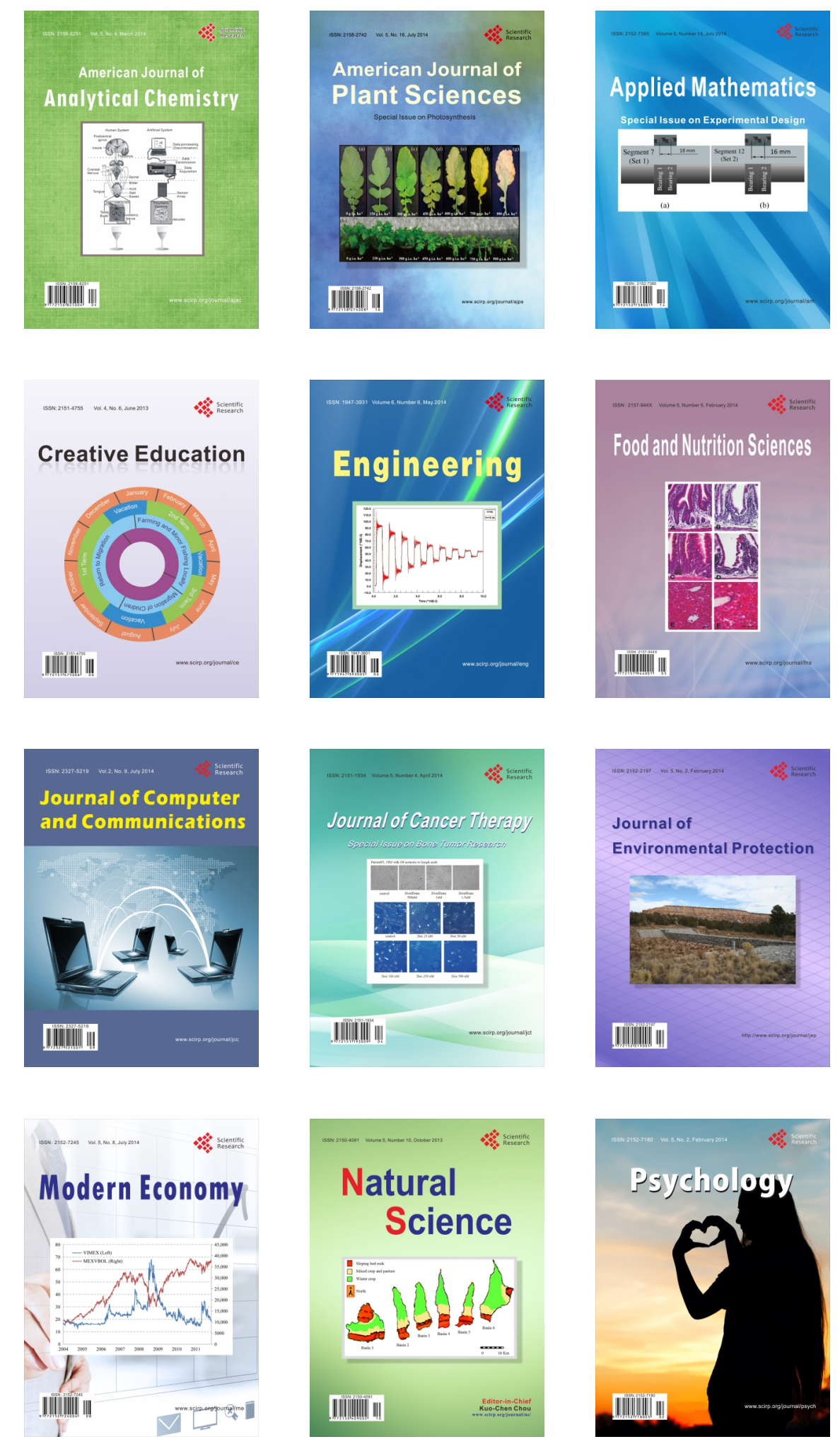